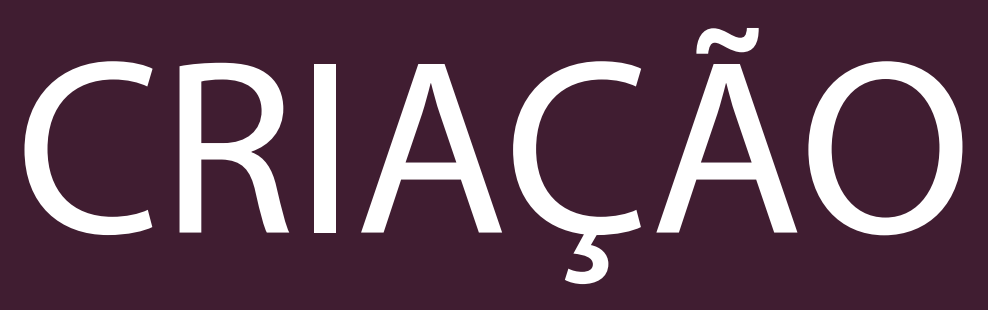





\section{HOMÔNIMO / \\ MEMÓRIAS DO CÁRCERE}

- ZAINNE LIMA DA SILVA

\section{HOMÔNIMO}

estupro não é uma palavra

que eu trate em verso

mas apenas em prosa

é esse assunto que exige

o mastigável, liquefeito, processado

papinha de micro-ondas

ninguém quer ver estupro

saindo da boca de bebê

nem de idoso

muito menos de boca de pastor

no meio de uma oração

não se diz bom dia com estupro

nem boa noite, eu te amo

bom te ver novamente

estupro não aparece em música

em performance artística

quadro de parede

não aparece estupro, inclusive

em livro de escola, no primário

secundário, universitário, no magistrativo

não aparece

estupro não aparece no hino nacional

no à bandeira, menos ainda

em comício nem proclamação 
jamais aparecerá, que esteja registrado

anteontem era natal

ontem, carnaval; amanhã é páscoa

depois de amanhã é são joão

dia das crianças, não há para que falar de estupro

jesus nasceu, cresceu

ensinou, fez milagre

dividiu o pão, os peixes

o chicote e o perdão

morreu, ressuscitou

e nunca foi estuprado

estupro

é substantivo, nunca verbo

as irmãs não foram estupradas

as vizinhas também não

nem mesmo as quengas

nunca ouviu-se falar

de um homem que conhecesse

um estuprador

e de um homem que dissesse

eu estuprei uma mãe de santo?

o Brasil nasceu do estupro

e eu mesma só não nasci

porque houve aborto legal e gratuito

ainda no século $X X$

(a que pátria pertence o sexo consentido?

a qual o amor?)

estupro

palavra que enrola a língua

do pobre e do rico

escrevo aqui para que não haja dúvidas

eu fui estuprada. 


\title{
MEMÓRIAS DO CÁRCERE
}

\author{
amei homens \\ cujo prazer era gozar o silêncio \\ principalmente quando deviam explicações \\ para eles silenciar era uma escolha \\ um repouso para quem o direito do dizer \\ esteve sempre e sempre garantido \\ eu descobri o poder da garganta \\ para que calar se estive muda nos corpos \\ de minhas tetra tatara bisa avó \\ se estive quieta em Eva e em Maria \\ se meu único som legítimo fora o gemido \\ de choro dentro de um navio negreiro \\ o silêncio para mim é cárcere \\ não fico quieta não ficarei \\ gritarei cada vez mais alto em prateleiras públicas \\ forrando os livros com os meus nervos \\ de aço sim mas humanizados e raivosos \\ furiosos desvairados excelentemente polidos \\ no uso poético de cada palavra minha \\ se um dia me calar será em fogueira de papéis \\ censura aniquilação do pensamento da expressão \\ ainda depois de morta \\ estarei cá em meus livros a falar \\ sobre memórias de libertação.
}

ZAINNE LIMA DA SILVA - É autora de Pequenas ficções de memória, publicado pela Editora Patuá (2018). Possui textos nas publicações Jovem Afro e Cadernos Negros (Quilombhoje); Raizes (Ed. Venas Abiertas); As coisas que as mulheres escrevem (Ed. Desdêmona); Nem uma a menos (Editora Versejar - no prelo); 